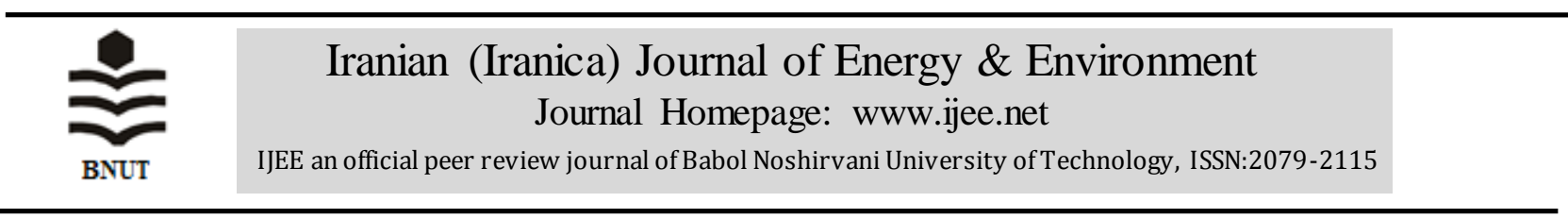

\title{
An Experimental Study on Cooling the Photovoltaic Modules by Fins to Improve Power Generation: Economic Assessment
}

\author{
M. Firoozzadeh ${ }^{1}$, A. H. Shiravi ${ }^{1 *}$, M. Shafiee $^{2}$ \\ ${ }^{1}$ Department of Mechanical Engineering, Jundi-Shapur University of Technology, Dezful, Iran \\ ${ }^{2}$ Department of Chemical Engineering, Jundi-Shapur University of Technology, Dezful, Iran
}

\section{PAPER I NFO}

\section{Paperhistory:}

Received 15 March 2019

Accepted in revised form 24 June 2019

\section{Keywords:}

Economic

Energy Analysis

Fin

Photovoltaic

\begin{abstract}
A B S T R A C T
Photovoltaic (PV) power plant is one of the most important renewable power generation methods, which is rapidly developing. One of the weak points of PV power plants is the negative effects of increasing the cells temperature on their power generation. In this study, a simple and low cost method is proposed to reduce the temperature of these panels. The use of fins has been proven in many industrial applications and here it is used as coolant of PV panel. This experiment was performed in maximum operating temperature of photovoltaic modules which is known as $85^{\circ} \mathrm{C}$. By using numbers of aluminum fins on the back surface of photovoltaic panels under two different irradiation, the temperature reduction up to $7.4{ }^{\circ} \mathrm{C}$ was observed, and this reduction leads to $2.72 \%$ increasing in efficiency. Finally, an economical assessment of the offered cases based on output power of PV panels carried out, which shows a suitable economic justifiability.
\end{abstract}

doi: $10.5829 /$ ijee.2019.10.02.02

\section{INTRODUCTION}

Nowadays, due to the technological advancements, the demand for power feels more than before. To this aim, most countries in the world are moving towards the use of clean and renewable energy. This process is developing rapidly. Therefore, each country has selected one or more renewable methods for electricity production, according to its geographical and climatic condition.

Solar energy is very benefited and it has different activities can be perform by means of light and heat of the sun, such as: solar desalination [1], solar heater [2], ventilation system [3], solar dryer [4] and so forth. From the sun, you can produce electricity by two approches: heat and light. Photovoltaic technology is the science of converting sunlight into electricity. Unfortunately, increasing the temperature of PV cells leads to reduction of the efficiency and output power of the panel. Many researchers reported that each $1^{\circ} \mathrm{C}$ rising in the temperature of PV panels, caused to degrade of the efficiency by about 0.45 to $0.5 \%[5,6]$. Several methods have been suggested to decrease losses: Nanofluid, Phase Change Material (PCM), thermoelectric, etc.

Cooling by nanofluids is one of the method to control the temperature of PV cells. Aberoumand et al. [7] conducted an experimental research on improving the

* Corresponding Author Email: ahshiravi@ jsu.ac.ir (Amir Hossein Shiravi) performance of PV modules by silver/water nanofluid. They also investigated both energy and exergy analysis. It is reported that in turbulent flow, by $4 \mathrm{wt} \%$ of mentioned nanofluid, the output power will increased up to $35 \%$, compared by conventional PV module. Firoozzadeh et al. [8] were investigated experimentally of using Carbon nanofluid with concentration of $1 \mathrm{wt} \%$ as PV cells coolant. They compared the results of the mentioned system by conventional PV panel. Finally a decline of about $50^{\circ} \mathrm{C}$ for temperature was shown. This temperature reduction leads to increasing the electrical efficiency up to about $5.75 \%$. Ghadiri et al. [9] conducted an experimental study by a solar simulator under two different irradiation of 600 and 1100 $\mathrm{W} / \mathrm{m}^{2}$. They used $\mathrm{Fe}_{3} \mathrm{O}_{4} /$ water (ferro-fluid) as nano fluid and they reported a significant increase of about $45 \%$ in efficiency.

PCMs in photovoltaic systems is used in order to make delay of temperature rising of PV cells. Huang [10], created irradiation of $750 \mathrm{~W} / \mathrm{m}^{2}$ on a PV panel, by a $1000 \mathrm{~W}$ projector. He used GR40 behind PV panel as PCM, and showed for about $150 \mathrm{~min}$, this material can kept the panel temperature below $51^{\circ} \mathrm{C}$. A $2 \mathrm{D}$ simulation has been done by Biwole et al. [11] to investigate the effects of RT25 as PCM under exactly irradiation of $1000 \mathrm{~W} / \mathrm{m}^{2}$. In this study, a number of fins were used behind the PV panel and inside the PCM. The results showed that addition of PCM, for about 80 min, can maintain the temperature of PV panel under $40^{\circ} \mathrm{C}$. Firoozzadeh et al. [12] had an experimental study to 
compare three cases of PV panel as: conventional PV panel, PV panel with PCM and PV panel with both PCM and fins. PEG 600 was used as PCM. This experiment was performed in critical operating temperature of PV cells, which is known as $85^{\circ} \mathrm{C}$. Finally, the results showed that PV/PCM system has the best performance, whereas the temperature difference of more than $34^{\circ} \mathrm{C}$ was created between this $\mathrm{PV}$ panel with conventional one.

Thaib et al. [13] used paraffin and bee-wax having melting point of $47.6{ }^{\circ} \mathrm{C}$ and $51{ }^{\circ} \mathrm{C}$, respectively, as PCMs in hot climate of Banda Aceh, Indonesia. The final results showed a difference in range of $0.5 \%$ to $1.7 \%$ in electrical efficiency of with and without PCMs modules.

Atkin and Farid [14] had an experimental and numerical research on increasing the effciency of PV cells by using PCM and fins. Their experiments were carried out by a solar simulator in an indoor condition. Finally, it was reported that after 12 hours from the beginning of experimental run, the mentioned PV panel had more than $8 \%$ higher efficiency compared with conventional PV panel. In a similar study, Khanna et al. [15] investigated the effect of using PCM and fins simultaneously, to decrease the rate of increasing temperature of PV cells. RT25HC was used as PCM. Their study was focused on finding the optimum state of distance and thickness of fins.

Moreover, cooling by water circulation [16-19], artificial air flow [20-22], and thermoelectric (TE) cooling [23-25] are the other reported methods to keep the temperature of PV modules down.

As reported in literature, researchers were investigated fins and PCM simultaneously, on the back surface of PV modules. The main aim of this study is to investigating the photovoltaic panels only by fin, as a simple and scientific method. It must be noted that in this study, we test the PV panels under the critical operating temperature which is known as $85^{\circ} \mathrm{C}$. Moreover, an economic analysis of using fins was carried out in this study.

\section{MATERIAL AND METHOD}

\section{Experimental set-up}

Two identical polycrystalline PV panels made by Yingli Solar Company of China, with power of $60 \mathrm{~W}$ were used. The electrical parameters of mentioned photovoltaic modules are presented in Table 1. In order to observe the effect of using fins, two cases were studied:

Case 1: Conventional PV panel (without fins)

\section{Case 2: PV Panel with fins}

Figure 1, shows a schematic view of second case. Moreover, an overview of with and without fins PV modules is exhibited in Figure 2. It should be noted that all of experiments was done in an indoor condition by adjustable ambient temperature and emitted radiation and two tungsten projectors with the power of $1000 \mathrm{~W}$ were used as irradiation supply. In order to measure the amount of radiation emitted to the PV panel, TES-132 solar power meter was used. it was determined that for 60 and $50 \mathrm{~cm}$ vertical distances of the projectors from the panels, 420 and $630 \mathrm{~W} / \mathrm{m}^{2}$ radiation and the temperature of 65 and $85{ }^{\circ} \mathrm{C}$ can be achieved, respectively.
In the second case, numbers of 10 aluminum fins with $4 \mathrm{~cm}$ width and thermal conductivity of $204 \mathrm{~W} / \mathrm{m} . \mathrm{K}$ were used behind the PV panel. The DS-18B20 digital thermometer sensors are used. These sensors have accuracy of $0.5^{\circ} \mathrm{C}$ and measurable temperature range of $-55{ }^{\circ} \mathrm{C}$ to $+125{ }^{\circ} \mathrm{C}$. The exact position of sensors is shown in Figure 3.

TABLE 1. The main thechnical parameters of PV modules

\begin{tabular}{lc}
\hline Module characteristics & Value \\
\hline Power output $\left(P_{\operatorname{Max}}\right)[\mathrm{W}]$ & 60 \\
Module efficiency $\left(\eta_{m}\right)[\%]$ & 14.4 \\
Open-circuit voltage $\left(V_{O C}\right)[\mathrm{V}]$ & 22.86 \\
Short-circuit current $\left(I_{S C}\right)[\mathrm{A}]$ & 3.44 \\
Critical operating temperature $\left[{ }^{\circ} \mathrm{C}\right]$ & 85 \\
Module type & polycrystalline \\
\hline
\end{tabular}

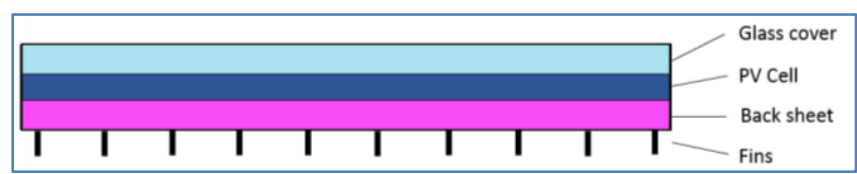

Figure 1. A schematic of the proposed PV panel

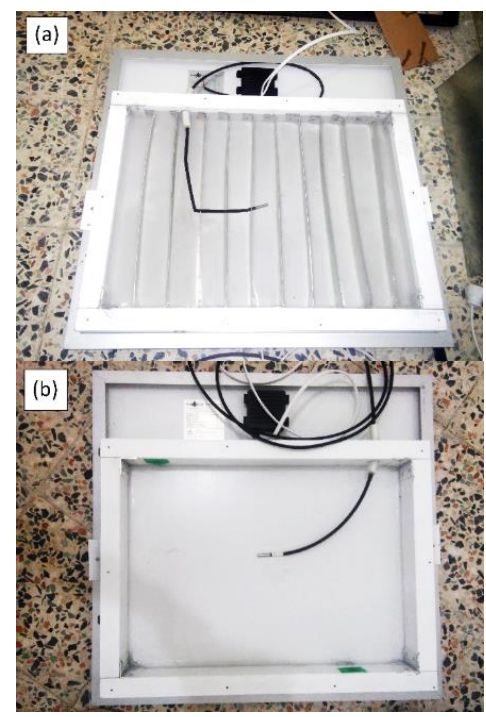

Figure 2. A view of with and without fins PV panels

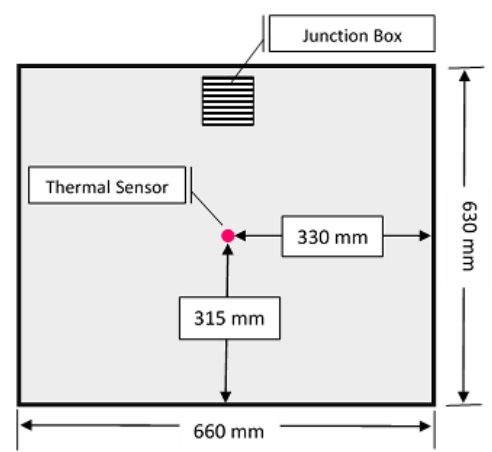

Figure 3. Exact position of thermal sensor 


\section{Governing equations}

The efficiency value written in panel's catalogue is measured based on the Standard Test Conditions (STCs), which is defined as: cell temperature of $25^{\circ} \mathrm{C}$, solar irradiance of $1000 \mathrm{~W} / \mathrm{m}^{2}$ and air mass $\mathrm{AM}=1.5$. To calculate the efficiency of PV panels, we need to define the output and also input power as follows:

$P_{\text {out }}=V_{m p} I_{m p}$

$P_{\text {in }}=G A$

where, $V_{m p}$ and $I_{m p}$ are voltage in $(\mathrm{V})$ and current in (A), respectively, which received from data-logger. Moreover, $G$ is irradiation of sun in $\left(\mathrm{W} / \mathrm{m}^{2}\right)$ and $\mathrm{A}$ is the PV cells area in $\left(\mathrm{m}^{2}\right)$. Thus, the efficiency of PV panels $(\eta)$ is calculated by Equation (3):

$\eta=\frac{P_{\text {out }}}{P_{\text {in }}}=\frac{V_{\text {oc }} I_{S C} \cdot F F}{G A}$

where $V_{o c}$ is open circuit voltage in (V) and $I_{s c}$ is short circuit current in (A). Moreover, in equation (3), $F F$ is the fill factor and is defined as folllows:

$F F=\frac{V_{m p} I_{m p}}{V_{o c} I_{s c}}$

\section{RESULTS AND DISCUSSION \\ Temperature variation}

Figure 4 illustrates the temperature variation for mentioned PV modules. It is obvious from this figure that using fins have been able to demonstrate its impacts on decreasing the panel's temperature for two irradiation of 630 and $420 \mathrm{~W} / \mathrm{m}^{2}$. Using fins, leads to decrease the temperature up to 7 and $5^{\circ} \mathrm{C}$, respectively for these irradiations. Although, the temperature difference may seems low, but it should be noted that this difference in temperature is created by a simple approch with low cost. The economic analysis is also reported.

\section{Efficiency variation}

As already mentioned, increasing the temperature of photovoltaic modules leads to reduce their efficiency. Figure 5 shows this efficiency variation with resoect to time. According to this diagram, it is known that in radiation of $630 \mathrm{~W} / \mathrm{m}^{2}$, the value of $2.34 \%$ and for $420 \mathrm{~W} / \mathrm{m}^{2}$ the value of $2.68 \%$ differences in efficiencies were determined.

\section{Power}

As expected, the output power of photovoltaic modules decreased with temperature growth during time which is demonstrated in Figure 6. By comparing Figure 5 and Figure 6, it can be seen that these diagrams have similar variation rates. The reason of this likeness is that the numerator of formula for calculating the efficiency (see equation 3 ) is power output of the photovoltaic module and denominator of that equation is also constant for a given value of irradiation.

In order to provide a better mindset of this power difference, the comparis on between the power output of a 10 $\mathrm{kW}$ photovoltaic power plant has been calculated with the data of steady state, for two modes of with and without fins. This comparison is shown in Figure 7. As clear, the power difference of $1.328 \mathrm{~kW}$ was estimated by proposed
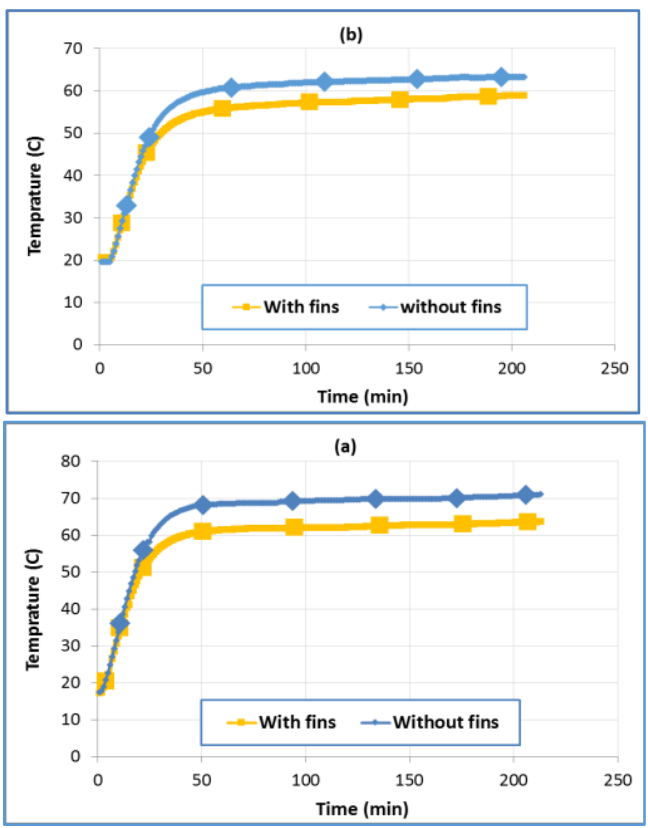

Figure 4. The variation of temperature under irradiation of (a) $630 \mathrm{~W} / \mathrm{m}^{2}$ and (b) $420 \mathrm{~W} / \mathrm{m}^{2}$
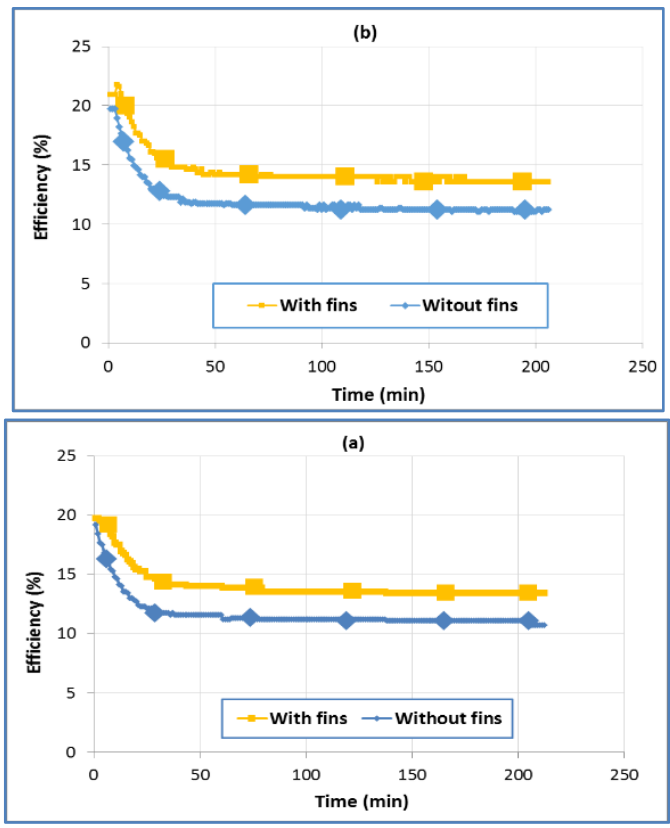

Figure 5. The variation of efficiency under irradiation of (a) $630 \mathrm{~W} / \mathrm{m}^{2}$ and (b) $420 \mathrm{~W} / \mathrm{m}^{2}$

case. This value is more than $20 \%$ difference for with and without fins modes.

According to the above presentation of data, we can calculate how much more PV panel is need to reach the power of $10 \mathrm{~kW}$ (based on the described conditions of this experiment). This calculation is presented in Table 2. Increase in required PV modules, is also leads to increase in initial cost of a PV power plant.

\section{Financial estimation}

Table 3 shows the total cost of cases. To economic viewpoint, here we define financial estimate (F.E.) 
parameter which is the ratio of cost per output power of each panel over time, as follows:

$F . E .=\frac{\text { Initial Cost }}{\text { output Power }}$

It is obvious that whatever F.E. be less, indicates that it is more economic. As illustrated in Figure 8, for entire duration of experiment, the curve of fins included panel, is lower than the non-fins one, which illustrates using fins is economical.
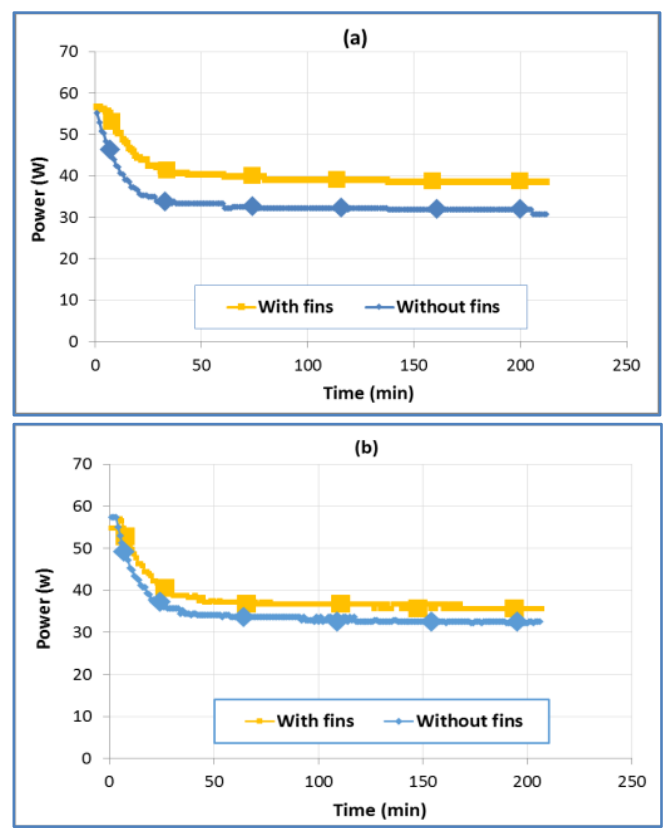

Figure 6. The variation of power output under irradiation of (a) $630 \mathrm{~W} / \mathrm{m}^{2}$ and (b) $420 \mathrm{~W} / \mathrm{m}^{2}$

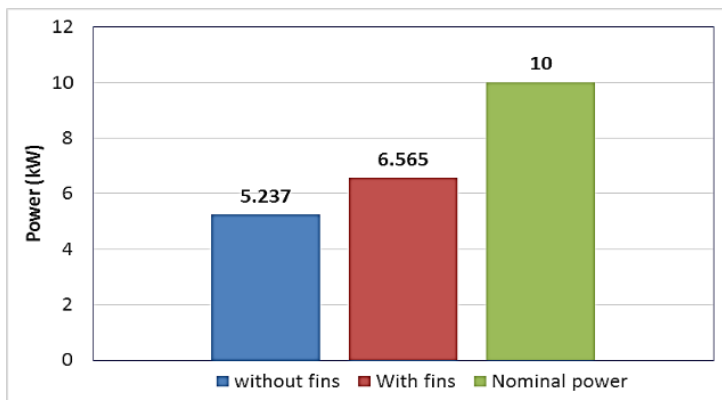

Figure 7. Comparison of output power for a $10 \mathrm{~kW}$ PV power plant between consider cases of this study

TABLE 2. Increase in required PV modules

\begin{tabular}{lcc}
\hline & Without fins & With fins \\
\hline $\begin{array}{l}\text { Increase in required PV } \\
\text { modules value }(\%)\end{array}$ & 47.63 & 34.35 \\
\hline
\end{tabular}

TABLE 3. Economic calculations of PV panels

\begin{tabular}{lccc}
\hline & PV Panel (\$) & Fins (\$) & Total Cost (\$) \\
\hline With Fins & 47 & 4 & 51 \\
Without Fins & 47 & - & 47 \\
\hline
\end{tabular}

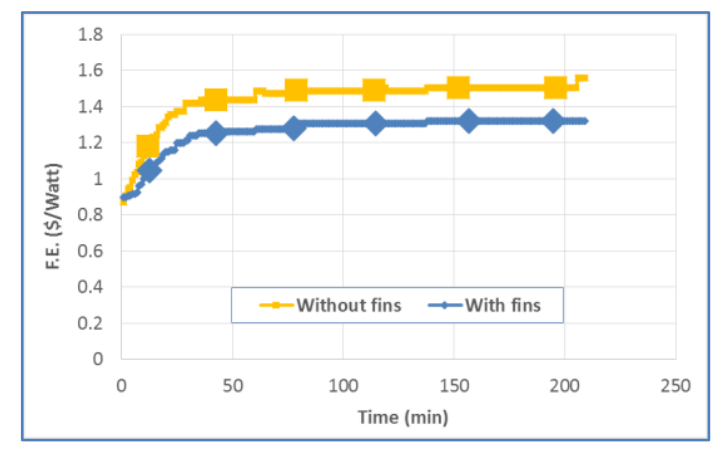

Figure 8. Financial Estimate of considered PV panels

\section{CONCLUSION}

Here, in order to improving the performance of PV modules, using aluminum fins has been proposed. Both experimental and economical studies were conducted to ensure from industrial availability of this scheme. The results can be summarized as follows:

1. For irradiations of $630 \mathrm{~W} / \mathrm{m}^{2}$ and $420 \mathrm{~W} / \mathrm{m}^{2}$, the maximum temperature differences of $5{ }^{\circ} \mathrm{C}$ and $7{ }^{\circ} \mathrm{C}$, were generated, respectively.

2. For irradiations of $630 \mathrm{~W} / \mathrm{m}^{2}$ and $420 \mathrm{~W} / \mathrm{m}^{2}$, the maximum efficiency difference of 2.68 and $2.34 \%$, were determined, respectively.

3. For a $10 \mathrm{~kW}$ photovoltaic power plant with the proposed scheme, the power difference of $1.328 \mathrm{~kW}$ was calculated, which this value is about $20.22 \%$ difference for with and without fins modes.

4. Using fins is very beneficial from the financial viewpoint.

\section{REFERENCES}

1. G. Boligán Rojas, R. Lorenzo Ávila Rondon, A. Carolina Meléndez Gurrola, Mechanical Engineering Design Theory Framework for Solar Desalination Processes: A Review and Meta-Analysis, Iranian Journal of Energy and Environment; previously called: Iranica Journal of Energy \& Environment, 9(2), (2018), 137-145.

2. S. Dubey, G. Tiwari, Thermal modeling of a combined system of photovoltaic thermal (PV/T) solar water heater, Solar energy, 82(7), (2008), 602-612.

3. C. Arkar, S. Medved, Free cooling of a building using PCM heat storage integrated into the ventilation system, Solar Energy, 81(9), (2007), 1078-1087.

4. S. Yadav, V.P. Chandramohan, Numerical Analysis on Thermal Energy Storage Device With Finned Copper Tube for an Indirect Type Solar Drying System, Journal of Solar Energy Engineering, 140(3), (2018), 031009031013.

5. E. Skoplaki, J.A. Palyvos, On the temperature dependence of photovoltaic module electrical performance: A review of efficiency/power correlations, Solar energy, 83(5), (2009), 614-624. 
6. M. Chandrasekar, S. Rajkumar, D. Valavan, A review on the thermal regulation techniques for non integrated flat PV modules mounted on building top, Energy and Buildings, 86, (2015), 692-697.

7. S. Aberoumand, S. Ghamari, B. Shabani, Energy and exergy analysis of a photovoltaic thermal (PV/T) system using nanofluids: An experimental study, Solar Energy, 165, (2018), 167-177.

8. M. Firoozzadeh, A.H. Shiravi, M. Shafiee, Experimental Study on Photovoltaic Cooling System Integrated With Carbon Nano Fluid, Journal of Solar Energy Research, 3(4), (2018), 287-292.

9. M. Ghadiri, M. Sardarabadi, M. Pasandideh-fard, A.J. Moghadam, Experimental investigation of a PVT system performance using nano ferrofluids, Energy Conversion and Management, 103, (2015), 468-476.

10. M. Huang, P. Eames, B. Norton, Phase change materials for limiting temperature rise in building integrated photovoltaics, Solar Energy, 80(9), (2006), 1121-1130.

11. P.H. Biwole, P. Eclache, F. Kuznik, Phase-change materials to improve solar panel's performance, Energy and Buildings, 62, (2013), 59-67.

12. M. Firoozzadeh, A.H. Shiravi, M. Shafiee, Experimental and Analytical Study on Enhancing the Efficiency of the Photovoltaic Panels by Using the Polyethylene-Glycol 600 (PEG 600) as a Phase Change Material, Iranian Journal of Energy and Environment; previously called: Iranica Journal of Energy \& Environment, 10(1), (2019), 23-32.

13. R. Thaib, S. Rizal, Hamdani, T.M.I. Mahlia, N.A. Pambudi, Experimental analysis of using beeswax as phase change materials for limiting temperature rise in building integrated photovoltaics, Case Studies in Thermal Engineering, 12, (2018), 223-227.

14. P. Atkin, M.M. Farid, Improving the efficiency of photovoltaic cells using PCM infused graphite and aluminium fins, Solar Energy, 114, (2015), 217-228.

15. S. Khanna, K.S. Reddy, T.K. Mallick, Optimization of finned solar photovoltaic phase change material (finned pv pcm) system, International Journal of Thermal Sciences, 130, (2018), 313-322.

16. H. Bahaidarah, A. Subhan, P. Gandhidasan, S. Rehman, Performance evaluation of a PV (photovoltaic) module by back surface water cooling for hot climatic conditions, Energy, 59, (2013), 445-453.

17. S. Krauter, Increased electrical yield via water flow over the front of photovoltaic panels, Solar Energy Materials and Solar Cells, 82(1), (2004), 131-137.

18. T.T. Chow, W. He, J. Ji, An experimental study of façade-integrated photovoltaic/water-heating system, Applied Thermal Engineering, 27(1), (2007), 37-45.

19. H.-L. Tsai, Design and Evaluation of a Photovoltaic/Thermal-Assisted Heat Pump Water Heating System, Energies, 7(5), (2014), 3319-3338.

20. R. Kumar, M.A. Rosen, Performance evaluation of a double pass PV/T solar air heater with and without fins, Applied Thermal Engineering, 31(8), (2011), 14021410.

21. G. Mittelman, A. Alshare, J.H. Davidson, A model and heat transfer correlation for rooftop integrated photovoltaics with a passive air cooling channel, Solar Energy, 83(8), (2009), 1150-1160.

22. J.-H. Kim, J.-G. Ahn, J.-T. Kim, Demonstration of the performance of an air-type photovoltaic thermal (PVT) system coupled with a heat-recovery ventilator, Energies, 9(9), (2016), 728-742.

23. A. Makki, S. Omer, Y. Su, H. Sabir, Numerical investigation of heat pipe-based photovoltaicthermoelectric generator (HP-PV/TEG) hybrid system, Energy conversion and management, 112, (2016), 274 287.

24. J. Skovajsa, M. Koláček, M. Zálešák, Phase Change Material Based Accumulation Panels in Combination with Renewable Energy Sources and Thermoelectric Cooling, Energies, 10(2), (2017), 152-170.

25. G. Li, X. Chen, Y. Jin, Analysis of the Primary Constraint Conditions of an Efficient PhotovoltaicThermoelectric Hybrid System, Energies, 10(1), (2017), 20-31.

\begin{tabular}{|c|}
\hline DOI: 10.5829/ijee.2019.10.02.02 \\
\hline جكيده \\
\hline 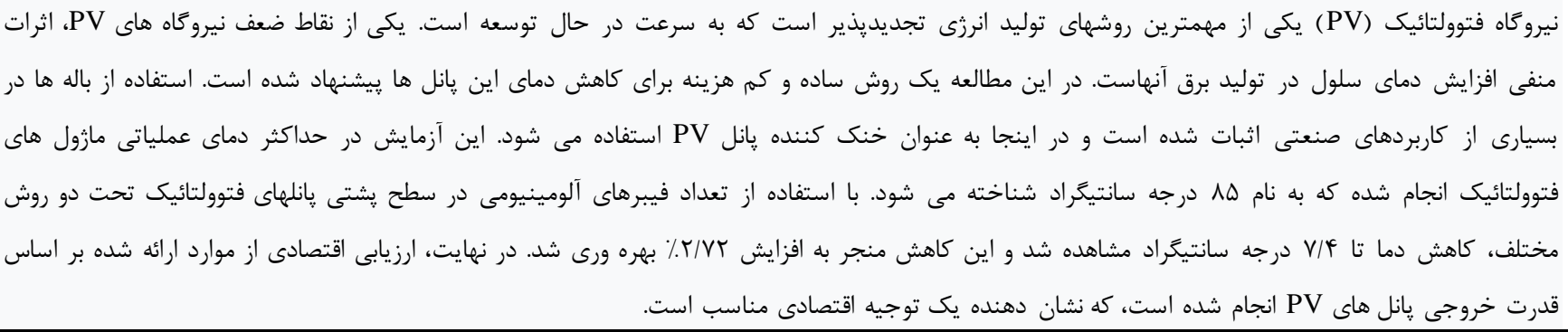 \\
\hline
\end{tabular}

